\title{
PENDIDIKAN AGAMA DI SEKOLAH UMUM KURUN WAKTU 2003 s.d. 2014
}

\author{
Mulkeis \\ Teacher of PAI Junior Hight School Negeri 2 Padangsidimpuan, North Sumatera \\ Jl. Ade Irma Suryani Nasution, No. 1, Ujung Padang, Padang Sidempuan Selatan 22732 \\ Email: mulkeismatondang@yahoo.co.id.
}

\begin{abstract}
Islamic education is a subject that gives the basics of Islamic religious knowledge to the learners. Through Islamic Education students will be expected to have faith and devotion to Allah., Virtuous noble character (moral noble), and have sufficient knowledge of Islam that has resistance at the same time can have a power filter to a variety of negative effects arising from the environment. However, the current reality shows that such expectations not reached its full potential. This is partly visible from the declining interest and motivation of learners studying Islamic education and the decline in religious practice learners in everyday life, for example lazy conducting worship, fight or not to obey their parents and teachers, fighting with fellow learners, lazy learning etc. Various problems and challenges faced in the implementation of Islamic religious education require introspection of all stakeholders in an effort to make improvements, so that the objectives of Islamic religious education in schools can be achieved optimally. It required sinergivitas of all related components, especially the Ministry of Religious Affairs, Ministry of Education and Culture and Local Government to make the perception of the implementation of Islamic religious education in schools.
\end{abstract}

Keywords: Education, moral values, Islamic Religious.

\begin{abstract}
Abstrak
Pendidikan Islam adalah subjek yang memberikan dasar-dasar pengetahuan agama Islam kepada peserta didik. Melalui Pendidikan Islam siswa akan diharapkan memiliki keimanan dan ketaqwaan kepada Allah. Akhlak mulia (moral yang mulia), dan memiliki pengetahuan yang cukup tentang Islam yang memiliki ketahanan pada saat yang sama dapat memiliki daya filter untuk berbagai efek negatif yang timbul dari lingkungan. Namun, kenyataan saat ini menunjukkan bahwa harapan tersebut tidak tercapai secara maksimal. Hal ini sebagian terlihat dari menurunnya minat dan motivasi peserta didik belajar pendidikan Islam dan penurunan peserta didik praktek keagamaan dalam kehidupan sehari-hari, misalnya ibadah melakukan malas, melawan atau tidak mematuhi orang tua dan guru mereka, berkelahi dengan sesama peserta didik, malas belajar dll. Berbagai masalah dan tantangan yang dihadapi dalam pelaksanaan pendidikan agama Islam membutuhkan introspeksi dari semua pemangku kepentingan dalam upaya untuk melakukan perbaikan, sehingga tujuan pendidikan agama Islam di sekolah-
\end{abstract}


FITRAH Vol.01 No. 1 Januari - Juni 2015

sekolah dapat dicapai secara optimal. Untuk itu diperlukan sinergivitas dari semua komponen terkait, khususnya Kementerian Agama, Kementerian Pendidikan dan Kebudayaan dan Pemerintah Daerah untuk membuat persepsi pelaksanaan pendidikan agama Islam di sekolah-sekolah

Kata Kunci: Education, moral values, Islamic Religious

\section{PENDAHULUAN}

Penyelenggaraan Pendidikan Agama Islam merupakan bagian penting dari Sistem Pendidikan Nasional, yang tentunya memberikan sumbangan besar terhadap pencapaian tujuan pendidikan nasional, terutama dalam mewujudkan manusia yang beriman dan bertakwa kepada Tuhan Yang Maha Esa. Kondisi ini menyebabkan Pendidikan Agama Islam ditetapkan sebagai salah satu mata pelajaran pokok yang diberikan di setiap jenjang pendidikan yang ada di Indonesia. Hal ini pula menyebabkan Pendidikan Agama Islam di Sekolah umum penting untuk tetap dipertahankan dan ditingkatkan kualitasnya.

Pendidikan Agama Islam merupakan mata pelajaran yang memberikan dasar-dasar pengetahuan agama Islam kepada peserta didik. Melalui Pendidikan Agama Islam diharapkan peserta didik akan memiliki keimanan dan ketakwaan terhadap Allah swt., berbudi pekerti yang luhur (berakhlak yang mulia), dan memiliki pengetahuan yang cukup tentang Islam, sehingga memiliki ketahanan sekaligus dapat memiliki daya filter terhadap berbagai dampak negatif yang muncul dari lingkungannya.

Harapan di atas tentu akan tercapai jika penyelenggaraan Pendidikan Agama Islam benar-benar bermutu. Namun realitas saat ini menunjukkan bahwa harapan tersebut belum tercapai secara maksimal. Hal ini antara lain tampak dari menurunnya minat dan motivasi peserta didik belajar Pendidikan Agama Islam dan menurunnya pengamalan agama peserta didik dalam kehidupan sehari-hari, misalnya malas melaksanakan ibadah, melawan atau tidak menuruti perintah orangtua dan guru, berkelahi dengan sesama peserta didik, malas belajar dan sebagainya.

Untuk meningkatkan mutu penyelenggaran pendidikan agama Islam di sekolah umum tentu perlu dukungan dari semua aspek yang terlibat dalam penyelenggaraan pendidikan tersebut, di antaranya adalah Peraturan Perundang-Undangan, Kurikulum, Sarana dan Prasarana, Tenaga Pendidik, dan Peserta Didik. Dengan adanya dukungan dari aspek-aspek tersebut diharapkan penyelenggaraan pendidikan agama di Sekolah umum akan semakin berkualitas. Sehubungan dengan hal di atas, dalam tulisan ini dibahas tentang perkembangan pendidikan agama Islam dari segi perundangan, kurikulum, tenaga pendidik dan peserta didik. 


\section{PERKEMBANGAN PENDIDIKAN AGAMA DI SEKOLAH 2003 S.D. 2014}

\section{Peraturan Perundang-undangan}

Pada tahun 2003 Majelis Permusyawaratan Rakyat Republik Indonesia menetapkan Undang-Undang No. 20 tahun 2003 tentang Sistem Pendidikan Nasional. Pada Bab II Pasal 3 dijelaskan bahwa Pendidikan nasional bertujuan untuk berkembangnya potensi peserta didik agar menjadi manusia yang beriman dan bertaqwa kepada Tuhan Yang Maha Esa, berakhlak mulia, sehat, berilmu, cakap, kreatif, mandiri, dan menjadi warga negara yang demokratis serta bertanggungjawab." ${ }^{1}$ Dari tujuan di atas tampak bahwa tujuan utama dari penyelenggaraan pendidikan nasional adalah manusia yang beriman dan bertaqwa kepada Tuhan Yang Maha Esa. Untuk mencapai tujuan tersebut tentunya perlu dilaksanakan pendidikan agama, mulai dari tingkat dasar sampai perguruan tinggi. Hal ini sesuai dengan pasal 12 ayat 1 Undang-Undang Nomor 20 Tahun 2003 dijelaskan "Setiap peserta didik pada satuan pendidikan berhak mendapatkan pendidikan agama sesuai dengan agama yang dianutnya dan diajarkan oleh pendidik yang seagama". ${ }^{2}$

Untuk melaksanakan ketentuan Pasal 12 ayat (4), Pasal 30 ayat (5), dan Pasal 37 ayat (3) Undang-Undang Nomor 20 Tahun 2003 tentang Sistem Pendidikan Nasional, pemerintah memandang perlu menetapkan Peraturan Pemerintah tentang Pendidikan Agama dan Pendidikan Keagamaan. Untuk itu dikeluarkan Peraturan Pemerintah Republik Indonesia Nomor 55 Tahun 2007 Tentang Pendidikan Agama Dan Pendidikan Keagamaan, pada tanggal 2 Oktober 2007.3 Peraturan Pemerintah ini tentu memerlukan petunjuk penyelenggaraan yang dikeluarkan oleh instansi terkait.

Dalam rangka pelaksanaan Peraturan PemerintahNomor 55 Tahun 2007 tentang Pendidikan Agama danPendidikan Keagamaan, Kementerian Agama memandang perlu menetapkan Peraturan Menteri Agama tentang Pengelolaan Pendidikan Agama PadaSekolah. Untuk itu dikeluarkanlah Peraturan Menteri Agama Republik Indonesia Nomor 16 Tahun 2010 Tentang Pengelolaan Pendidikan Agama Pada Sekolah pada tangga 6 Desember $2010 .{ }^{4}$

Pada tahun 2011 Kementerian Agama Republik Indonesia mengeluarkan Keputusan Menteri Agama Republik Indonesia Nomor 211 Tentang Pedoman Pengembangan Standar Nasional Pendidikan Agama Islam Pada Sekolah, yang isinya terdiri dari Pedoman Pengembangan Standar Isi Pendidikan Agama Islam, Pedoman Pengembangan Standar Proses Pendidikan Agama Islam, Pedoman Pengembangan

\footnotetext{
${ }^{1}$ Undang-Undang No. 20 Tahun 2003 Tentang Sistem Pendidikan Nasional, Bab II Pasal 3.

${ }^{2}$ Undantg-UndangNo. 20 Tahun 2003 Tentang Sistem Pendidikan Nasional, Pasal 12 ayat 1.

${ }_{3}^{3}$ Presiden Republik Indonesia, Peraturan Pemerintah Republik Indonesia Nomor 55 Tahun 2007 Tentang Pendidikan Agama Dan Pendidikan Keagamaan (Jakarta: Sekretariat Negara, 2007), hlm. 1.

${ }^{4}$ Menteri Agama Republik Indonesia, Peraturan Menteri Agama Republik Indonesia Nomor 16 Tahun 2010 Tentang Pengelolaan Pendidikan Agama Pada Sekolah (Jakarta: Sekretariat Negara, 2010), hlm. 1.
} 
FITRAH Vol.01 No. 1 Januari - Juni 2015

Standar Kompetensi Lulusan Pendidikan Agama Islam, Pedoman Pengembangan Standar Pendidik dan Kependidikan Pendidikan Agama Islam, Pedoman Pengembangan Standar Sarana dan Prasarana Pendidikan Agama Islam, Pedoman Pengembangan Standar Pengelolaan Pendidikan Agama Islam, Pedoman Pengembangan Standar Pembiayaan Pendidikan Agama Islam, dan Pedoman Pengembangan Standar Penilaian Pendidikan Agama Islam. ${ }^{5}$

Berdasarkan Uraian di atas tampak bahwa telah dilakukan beberapa regulasi dalam rangka pelaksanaan Pendidikan Agama di Sekolah Umum. Undang-undang, Peraturan Pemerintah, Peraturan Menteri Agama dan Kepututusan Menteri Agama yang diuraikan di atas merupakan paying hukum, sekaligus pedoman dalam penyelenggaraan Pendidikan Agama Islam di sekolah.

\section{Kurikulum}

Kurikulum pendidikan agama yang dilaksanakan di sekolah umum mengacu kepada kurikulum pendidikan yang berlaku secara umum di Indonesia. Dalam Perkembangannya, sejak tahun 2003 kurikulum pendidikan di Indonesia telah mengalami beberapa kali perubahan.Undang-Undang Republik Indonesia No. 20 Tahun 2003 pasal 37 ayat 1 menyatakan bahwa "pendidikan dasar dan menengah wajib memuat pendidikan agama, pendidikan kewarganegaraan, bahasa, matematika, ilmu pengetahuan alam, ilmu pengetahuan sosial, seni budaya, pendidikan jasmani dan olahraga, keterampilan/kejuruan dan muatan lokal" ${ }^{6}$

Implementasi Undang-Undang Nomor 20 tahun 2003 tentang Sistem Pendidikan Nasional dijabarkan ke dalam sejumlah peraturan, antara lain Peraturan Pemerintah Nomor 19 Tahun 2005 tentang Standar Nasional Pendidikan. Dalam dokumen ini dibahas standar isi sebagaimana dimaksud oleh Peraturan Pemerintah Nomor 19 Tahun 2005, yang secara keseluruhan mencakup:

a. Kerangka dasar dan struktur kurikulum yang merupakan pedoman dalam penyusunan kurikulum pada tingkat satuan pendidikan,

b. Beban belajar bagi peserta didik pada satuan pendidikan dasar dan menengah,

c. Kurikulum tingkat satuan pendidikan yang akan dikembangkan oleh satuan pendidikan berdasarkan panduan penyusunan kurikulum sebagai bagian tidak terpisahkan dari standar isi, dan

5Menteri Agama Republik Indonesia, Keputusan Menteri Agama Republik Indonesia Nomor 211 Tahun 2011 Tentang Pengemnbangan Standar PAI Pada Sekolah (Jakarta: Kementerian Agama RI, 2011), hlm. 3.

${ }^{6}$ Undang-Undang No. 23 Tahun 2003, Pasal 37 ayat 1. 
d. Kalender pendidikan untuk penyelenggaraan pendidikan pada satuan pendidikan jenjang pendidikan dasar dan menengah. ${ }^{7}$

Kurikulum 2004 lebih populer dengan sebutan KBK (kurikulum Berbasis Kompetensi) lahir sebagai respon dari tuntutan reformasi, diantaranya UU No 21999 tentang pemerintahan daerah, UU No 25 tahun 2000 tentang kewenangan pemerintah dan kewenangan propinsi sebagai daerah otonom, dam Tap MPR No IV/MPR/1999 tentang arah kebijakan pendidikan nasional. Scharg dalam Omar Hamalik menjelaskan bahwa pendidikan berbasis kompetensi menitikberatkan pada pengembangan kemampuan untuk melakukan (kompetensi) tugas-tugas tertentu sesuai dengan standard performance yang telah ditetapkan. ${ }^{8}$ Dengan demikian kurikulum pendidikan agama Islam pada masa ini disusun dengan mengacu pada upaya penyiapan individu yang mampu menguasai standar kompetensi dan kompetensi dasar yang ditetapkan.

Sesuai dengan Peraturan Pemerintah Nomor 19 Tahun 2005, maka mata pelajaran Pendidikan Agama Islam masuk kepada kelompok mata pelajaran agama dan akhlak mulia.Demikian juga dalam Kurikulum Tahun 2006 atau yang lebih dikenal dengan Kurikulum Tingkat Satuan Pendidikan. Kurikulum Tingkat Satuan Pendidikan (KTSP) adalah "kurikulum operasional yang disusun oleh dan dilaksanakan di masing-masing satuan pendidikan. KTSP terdiri dari tujuan pendidikan tingkat satuan pendidikan, struktur dan muatan kurikulum tingkat satuan pendidikan, kalender pendidikan, dan silabus". ${ }^{9}$ Ditinjau dari waktu yang dialokasikan untuk mata pelajaran pendidikan agama Islam, maka pada kurikulum 2006 (KTSP), jumlah jam pelajaran pendidikan agama Islam di sekolah umum mengalami sedikit perubahan pada tingkat Sekolah Dasar/MI, yaitu menjadi 3 jam pelajaran. Sedangkan untuk SMP/Sederajat dan SMA sederajat tetap 2 jam pelajaran. ${ }^{10}$ Sedangkan materi yang diajarkan terdiri dari Al-Qur'an dan Hadits, Aqidah, Akhlak, Fiqih, Tarikh dan Kebudayaan Islam.

Berkaitan dengan penyusunan kurikulum mata pelajaran pendidikan agama Islam, maka dalam Peraturan Menteri Agama Republik Indonesia Nomor 16 Tahun 2010 Tentang Pengelolaan Pendidikan Agama Pada Sekolah bab III pasal 7 dijelaskan sebagai berikut:

a. Kurikulum Pendidikan Agama disusun, dikembangkan, dan dilaksanakan oleh satuan pendidikan sesuai Standar Nasional Pendidikan.

${ }^{7}$ Lampiran peraturan menteri pendidikan nasional Nomor 22 tahun 2006 Tanggal 23 mei 2006, Standar Isi (Jakarta: BSNP, 2006), hlm. 1.

${ }^{8}$ Omar Hamalik ,Pengembangan Kurikulum (Bandung: Remaja Rosda Karya, 2006), hlm. 89.

${ }^{9}$ Ibid.

${ }^{10}$ Kunandar, Guru Profesional Implementasi Kurikulum Tingkat Satuan Pendidikan (KTSP) dan Sukses dalam Sertifikasi Guru (Jakarta: Raja Grafindo Persada, 2010), hlm. 220-224. 
b. Kurikulum Pendidikan Agama dikembangkan dengan memperhatikan potensi dan sumber daya lingkungan sekolah dan daerah.

c. Sekolah dapat menambah muatan kurikulum pendidikan agama berupa penambahan dan/atau pendalaman materi, serta penambahan jam pelajaran sesuai kebutuhan.

d. Kurikulum Pendidikan Agama sebagaimana dimaksud pada ayat (2) dan ayat (3) disahkan oleh Kepala Kantor Kementerian Agama Kabupaten/Kota. ${ }^{11}$

Berkaitan dengan materi pelajaran yang diberikan pada mata pelajaran pendidikan agama Islam di sekolah, maka melalui Keputusan Menteri Agama Nomor 211 Tahun 2011, ditegaskan bahwa materi yang diajarkan terdiri dari Al-Qur'an dan Hadits, Aqidah, Akhlak, Fiqih, Tarikh dan Kebudayaan Islam, dengan alokasi waktu untuk masingmasing kompetensi dasar dan materi per aspek harus memenuhi ketentuan persentase sebagai berikut: Alqur'an dan Hadis: 30\%, Keimanan: 20\%, Akhlak: 30\%, Fiqih/ Ibadah: 10\%, dan Tarikh $10 \% .{ }^{12} \mathrm{Pada}$ aspek pengamalan, maka pendidikan agama Islam dikelompokkan kepada: ${ }^{13}$

a. Pengamalan dalam Hubungan dengan Allah swt., yang meliputi: melaksanakan shalat waktu tepat waktu, shalat Jumat, puasa ramadhan, shalat berjamaah, shalat dhuha, membaca Al-Quran, berdzikir setelah shalat (tasbih, tahmid, takbir, tahlil, dan asma'ul husna), membiasakan mengucap kalimat thayyibah sesuai konteks, membiasakan melakukan sujud syukur, sujud tilawah, dan sujud sahwi, melakukan puasa sunah Senin-Kamis, membiasakan membaca buku-buku agama, terlibat aktif dalam kegiatan keagamaan (peringatan maulid Nabi Muhammad saw., Isra' Mi'raj, Nuzul Alqur'an, dan ibadah Qurban), dan membiasakan meneladani perilaku rasul.

b. Pengamalan dalam hubungan dengan diri sendiri terdiri dari: menjaga kebersihan diri sendiri, mengenal serta mengembangkan bakat dan potensi diri, mengenal pertumbuhan dan perkembangan diri, tidak berdandan berlebihan, tidak Tasyabbuh (berpenampilan seperti lawan jenis), menampilkan perilaku yang santun, menyampaikan pendapat atau saran dengan cara santun, melakukan interaksi dengan orang lain dengan santun, membiasakan membuat perencanaan dalam melakukan kegiatan, melaksanakan aturan yang ditetapkan, belajar disiplin dan bersemangat, ulet, tekun, kreatif dalam belajar, membuka diri, menerima perbedaan, dan menyukai perubahan, membiasakan mengelola keuangan sendiri dengan baik, gemar membaca dan belajar, membiasakan mengatur jadwal kegiatan sehari-hari (bangunpagi pada waktu shubuh), membatasi kegiatan yang kurang bermanfaat (bermain game,

\footnotetext{
${ }^{11}$ Menteri Agama Republik Indonesia, Peraturan Menteri, hlm. 6.

${ }^{12}$ Menteri Agama Republik Indonesia, Keputusan Menteri Agama Republik Indonesia, hlm. 39.

${ }^{13}$ Menteri Agama Republik Indonesia, Keputusan Menteri Agama Republik Indonesia, hlm. 37-38.
} 
chatting), tidak memiliki, mengakses, menyimpan dan menyebarkan fileatau folder pornografi/porno aksi dan kekerasan; dantidak mengkonsumsi makanan dan minuman yang dilarang.

c. Pengamalan dalam hubungan dengan sesama manusia meliputi: berperilaku hormat dan santun kepada orang tua (menyampaikan sesuatu dengan cara mendiskusikannya, meminta doa dan restu, bersedia membantu, tidak banyak menuntut, membiasakan berkonsultasi ketika ada masalah), berperilaku hormat dan santun kepada guru (berdiskusi, mengikuti saran dan nasehat, meminta doa, membiasakan berkonsultasi ketika ada masalah), berperilaku hormat dan santun kepada orang yang lebih tua(mengucapkan salam, bersedia membantu, menggunakan bahasa yang sopan), berperilaku hormat dan santun kepada teman (mengucap salam, menggunakan bahasa yang santun, tidak mengintimidasi, mampu menjaga sikap antara teman laki-laki dan perempuan, saling membantu dan menolong teman, saling pengertian dan berempati, menyayangi teman dengan tidak membeda-bedakanatas dasar ras, suku, budaya, gender, dan agama, tidak menyakitifisik maupun psikis, selektif dalam pergaulan), dan bergaul dengan masyarakat (aktif dalam kegiatan kemasyarakatan dan keagamaan, bergaul dengan baik, tidak apriori terhadap yang terjadi di sekitar rumah).

d. Hubungan manusia dengan lingkungan alam terdiri dari: menjaga kebersihan dan kelestarian lingkungan alam (mengambil dan membuang sampah pada tempatnya, sadar terhadap persoalan lingkungan dan mampu mengkritisi persoalan lingkungan, menanam/memelihara pohon, menyayangi, memelihara dan melindungi hewan, menghemat air dan listrik) dan membiasakan menjaga lingkungan dari kerusakan (kerjabakti untuk kebersihan lingkungan, tidak mencoret-coret dinding, penyelamatan/ pemeliharaan lingkungan hidup).

Pada Kurikulum 2013 waktu yang dioalokasikan untuk mata pelajaran pendidikan Agama Islam adalah 4 jam pelajaran untuk Sekolah Dasar, 3 jam pelajaran untuk SMP dan SMA/SMK. Hal ini menunjukkan ada peningkatan jumlah jam pelajaran dibandingkan dengan kurikulum 2006. Selain itu adanya kompetensi inti di dalam struktur kurikulumnya memberikan nilai tambah dapa penyelenggaraan Pendidikan Agama Islam. Kompetensi inti dirancang untuk setiap kelas. Melalui kompetensi inti, sinkronisasi horisontal berbagai kompetensi dasar antar mata pelajaran pada kelas yang sama dapat dijaga. Selain itu sinkronisasi vertikal berbagai kompetensi dasar pada mata pelajaran yang sama pada kelas yang berbeda dapat dijaga pula. Rumusan kompetensi inti menggunakan notasi sebagai berikut: (a) Kompetensi Inti-1 (KI-1) untuk kompetensi inti sikap spiritual, (b) Kompetensi Inti-2 (KI-2) untuk kompetensi inti sikap sosial, (c) 
Kompetensi Inti-3 (KI-3) untuk kompetensi inti pengetahuan; dan (d) Kompetensi Inti-4 (KI-4) untuk kompetensi inti keterampilan. ${ }^{14}$

Kompetensi Inti-1 sikap spiritual, memberikan ruang yang lebih luas dalam pelaksanaan pembelajaran pendidikan agama Islam di Sekolah karena setiap guru mata pelajaran berkewajiban untuk menanmkan nilai-nilai spiritual pada setiap pembelajaran yang dilaksanakannya. Hal ini tentu sangat membantu guru pendidikan agama Islam dalam implementasi pendidikan agama Islam di sekolah.

Berbagai persoalan yang muncul dalam implementasi Kurikulum 2013, mendorong pemerintah mengeluarkan Peraturan Menteri Pendidikan dan Kebudayaan Nomor 160 Tahun 2014 Tentang Pemberlakuan Kurikulum 2006 dan 2013, di mana pada pasal 1 dijelaskan: Satuan pendidikan dasar dan pendidikan menengah yang melaksanakan Kurikulum 2013 sejak semester pertama tahun pelajaran 2014/2015 kembali melaksanakan Kurikulum Tahun 2006 mulai semester keduatahun pelajaran 2014/2015 sampai ada ketetapan dari Kementerian untukmelaksanakan Kurikulum 2013. Selanjutnya pada pasal 2 ayat 1 dijelaskan pula bahwa Satuan pendidikan dasar dan pendidikan menengah yang telahmelaksanakan Kurikulum 2013 selama 3 (tiga) semester tetapmenggunakan Kurikulum 2013.15

Pemberlakuan kembali Kurikulum 2006 untuk sekolah yang sudah melaksanakan Kurikulum 2013 selama satu semester, merupakan kemunduran bagi pelaksanaan pendidikan agama Islam di Sekolah. Menyadari hal tersebut Kementerian Agama melalui Surat Edaran Nomor SE/D.3.1/PP.00/143/2015 Tentang Implementasi Kurikulum 2013 Pendidikan Agama Islam (PAI) Pada Sekolah, dimana dalam Surat Edaran tersebut dijelaskan bahwa Kementerian Agama tetap melanjutkan implementasi Kurikulum 2013 pada sekolah dengan memerintahkan Kantor Wilayah Kementerian Agama dan Kantor Kementerian Agama di wilayah dan daerah masing-masing untuk berkordinasi dengan Dinas Pendidikan di wilayah kerjanya. ${ }^{16}$ Dualisme peraturan ini tentu berpengaruh terhadap pelaksanaan pendidikan Agama di sekolah, sehingga perlu ada kearifan dari para pengambil kebijakan dalam rangka mempertahankan dan meningkatkan kualitas pembelajaran pendidikan agama Islam di sekolah.

14 Lampiran 1 Peraturan Menteri Pendidikan Dan Kebudayaan Nomor 58 Tahun 2014 Tentang Kurikulum 2013 Sekolah Menengah Pertama/Madrasah Tsanawiyah, hlm. 6.

${ }^{15}$ Menteri Pendidikan dan Kebudayaan Republik Indonesia, Peraturan Menteri Pendidikan dan Kebudayaan Nomor 160 Tahun 2014 Tentang Pemberlakuan Kurikulum 2006 dan 2013 (Kementerian Pendidikan dan Kebudayaan, 2014), hlm. 2.

${ }^{16}$ Surat Edaran Nomor SE/D.3.1/PP.00/143/2015 Tentang Implementasi Kurikulum 2013 Pendidikan Agama Islam (PAI) Pada Sekolah. 


\section{Tenaga Pendidik (guru)}

Guru merupakan komponen penting dalam penyelenggaraan pendidikan agama Islam. Untuk mempertegas keberadaan guru dalam Sistem Pendidikan Nasional, maka dalam Undang-Undang Nomor 20 Tahun 2003 Bab XI, diatur tentang tenaga pendidik, yaitu pada pasal 39, pasal 40, pasal 41, pasal 42, pasal 43, dan pasal 44. Pada pasal 41 tentang Pendidik dan Tenaga Kependidikandijelaskan:

a. Pendidik dan tenaga kependidikan dapat bekerja secara lintas daerah.

b. Pengangkatan, penempatan, dan penyebaran pendidik dan tenaga kependidikan diatur oleh lembaga yang mengangkatnya berdasarkan kebutuhan satuan pendidikan formal.

c. Pemerintah dan Pemerintah Daerah wajib memfasilitasi satuan pendidikan dengan pendidik dan tenaga kependidikan yang diperlukan untuk menjamin terselenggaranya pendidikan yang bermutu. ${ }^{17}$

Berdasarkan bunyi pasal 41 Undang-Undang Nomor 20 Tahun 2003 di atas dapat dipahami bahwa guru mempunyai hak dan kewajiban untuk ditempatkan di mana saja di wilayah Republik Indonesia, di mana pengangkatan, penempatan, dan penyebarannya disesuaikan dengan kebutuhan satuan pendidikan formal yang ada di suatu daerah. Dalam hal ini yang memfasilitasi pengangkatan, penempatan, dan penyebaran guru tersebut adalah pemerintah pusat dan daerah.

Perjuangan para pendidik untuk memiliki payung hukum dalam melaksanakan tugas dan tanggung jawabnya, dapat diwujudkan melalui penetapan Undang-Undang Nomor 14 Tahun 2005 Tentang Guru dan Dosen. Dalam Undang-Undang Nomor 14 Tahun 2005 pasal 2 dijelaskan sebagai berikut:

a. Guru mempunyai kedudukan sebagai tenaga professional pada jenjang pendidikan dasar, pendidikan menengah dan pendidikan anak usia dini pada jalur pendidikan formal yang diangkat sesuai dengan peraturan perundang-undangan.

b. Pengakuan kedudukan guru sebagai tenaga professional sebagaimana dimaksud pada ayat (1) dibuktikan dengan sertifikat pendidik. ${ }^{18}$

Kedua pasal di atas menunjukkan bahwa guru merupakan tenaga profesional yang dibuktikan oleh adanya sertifikat pendidik.Pada pasal 7 ayat 1 Undang-Undang Republik Indonesia Nomor 14 Tahun 2005 Tentang Guru dan Dosen, dijelaskan bahwa profesi guru dan dosen merupakan bidang pekerjaan khusus yang dilaksanakan berdasarkan prinsipprinsip berikut ini:

a. Memiliki bakat, minat, panggilan jiwa, dan idealisme.

${ }^{17}$ Undang-Undang No. 20 Tahun 2003, Pasal 41.

${ }^{18}$ Undang-Undang No. 14 Tahun 2005 Tentang Guru dan DosenSerta Undang-Undang No. 20 Tahun 2003 Tentang Sistem Pendidikan Nasional, Pasal 2. 
b. Memiliki komitmen untuk meningkatkan mutu pendidikan, keimanan, ketakwaan, dan akhlak mulia.

c. Memiliki kualifikasi akademik dan latar belakang pendidikan dengan bidang tugas.

d. Memiliki kompetensi yang diperlukan sesuai dengan bidang tugas.

e. Memiliki tanggung jawab atas pelaksanaan tugas keprofesionalan.

f. Memperoleh penghasilan yang ditentukan sesuai dengan prestasi kerja.

g. Memiliki kesempatan untuk mengembangkan keprofesionalan secara berkelanjutan dengan belajar sepanjang hayat.

h. Memiliki jaminan perlindungan hukum dalam melaksanakan tugas keprofesionalan.

i. Memiliki organisasi profesi yang mempunyai kewenangan mengatur hal-hal yang berkaitan dengan dengan tugas keprofesionalan guru. ${ }^{19}$

Prinsip-prinsip di atas sangat penting untuk menunjang profesionalitas guru, khususnya guru pendidikan agama Islam dalam melaksanakan tugas dan tanggung jawabnya sebagai pendidik, pengajar dan pelatih bagi peserta didiknya.

Sebagai tenaga professional, guru juga memiliki hak-hak dari profesinya. Dalam Undang-Undang Republik Indonesia Nomor 14 Tahun 2005 Tentang Guru dan Dosen, pasal 14 dijelaskan bahwa dalam melaksanakan tugas keprofesionalan, guru berhak:

a. Memperoleh penghasilan di atas kebutuhan hidup minimum dan jaminan kesejahteraan sosial.

b. Mendapatkan promosi dan penghargaan sesuai dengan tugas dan prestasi kerja.

c. Memperoleh perlindungan dalam melaksanakan tugas dan hak atas kekayaan intelektual.

d. Memperoleh kesempatan untuk meningkatkan kompetensi.

e. Memperoleh dan memanfaatkan sarana dan prasarana pembelajaran untuk menunjang kelancaran keprofesionalan.

f. Memiliki kebebasan dalam memberikan penilaian dan ikut menentukan kelulusan, penghargaan, dan/atau sanksi kepada peserta didik sesuai dengan kaidah pendidikan, kode etik guru, dan peraturan perundang-undangan.

g. Memperoleh rasa aman dan jaminan keselamatan dalam melaksanakan tugas.

h. Memiliki kebebasan untuk berserikat dalam organisasi profesi.

i. Memiliki kesempatan untuk berperan dalam menentukan kebijakan pendidikan.

j. Memperoleh kesempatan untuk mengembangkan dan meningkatkan kualifikasi akademik dan kompetensi, dan/atau

k. Memperoleh pelatihan dan pengembangan profesi dalam bidangnya. ${ }^{20}$

Dari uraian di atas dapat dipahami bahwa sebagai tenaga professional memiliki hak-hak yang harus dipenuhi oleh lembaga pendidikan dan Negara.Salah satu upaya yang sudah dilakukan untuk memenuhi hak-hak guru tersebut, adalah dengan

${ }^{19}$ Undang-Undang No. 14 Tahun 2005 Tentang Guru dan DosenSerta Undang-Undang No. 20 Tahun 2003 Tentang Sistem Pendidikan Nasional, Pasal 7 ayat 1.

${ }^{20}$ Undang-Undang No. 14 Tahun 2005 Tentang Guru dan DosenSerta Undang-Undang No. 20 Tahun 2003 Tentang Sistem Pendidikan Nasional, Pasal 14. 
memberikan tunjangan profesi kepada guru yang sudah memiliki sertifikat pendidik.Pemberian tunjangan profesi tersebut diharapkan dapat memotivasi para guru untuk meningkatkan kinerjanya. Dalam hal ini tunjangan professional guru pendidikan agama Islam disalurkan melalui Kementerian Agama.

Sejalan dengan penjelasan di atas, dalam Peraturan Pemerintah Nomor 16 Tahun 2010 bab IV tentang pendidik dan tenaga kependidikan pasal 13 dijelaskan sebagai berikut: “Guru Pendidikan Agama minimal memiliki kualifikasi akademik Strata 1/DiplomaIV, dari program studi pendidikan agama dan/atau program studi agama dari Perguruan Tinggi yang terakreditasi dan memiliki sertifikat profesi guru pendidikan agama". ${ }^{21}$ Selanjutnya pada pasal 14 dijelaskan bahwa:

a. Pengadaan guru pendidikan agama di sekolah yang diselenggarakan oleh Pemerintah dilakukan oleh Menteri.

b. Pengadaan guru pendidikan agama di sekolah yang diselenggarakan oleh Pemerintah Daerah dilakukan oleh Menteri dan/atau Pemerintah Daerah.

c. Pengadaan guru pendidikan agama di sekolah yang diselenggarakan oleh masyarakat dilakukan oleh sekolah atau penyelenggara pendidikan yang bersangkutan.

d. Dalam hal sekolah atau penyelenggara pendidikan sebagaimana dimaksud pada ayat (3) tidak dapat menyediakan guru pendidikan agama, Pemerintah atau Pemerintah Daerah wajib menyediakan guru sesuai dengan kebutuhan.

e. Penyediaan guru oleh Pemerintah atau Pemerintah Daerah sebagaimana dimaksud pada ayat (4) dilakukan setelah melalui proses verifikasi kelayakan untuk mendapat bantuan guru.

f. Kebutuhan jumlah guru pendidikan agama ditetapkan oleh Menteri. ${ }^{22}$

Untuk meningkatkan mutu guru pendidikan agama Islam, Kementerian Agama selaku penanggung jawab pembinaan guru pendidikan agama Islam melakukan berbagai kegiatan. Di antaranya adalah melalui pelatihan, workshop, apresiasi guru PAI kreatif, apresiasi guru PAI berprestasi, visiting guru PAI dan sebagainya. Selain itu dalam berbagai kegiatan sebagaian guru PAi diikutsertakan dalam kegiatan-kegiatan yang dilaksanakan Kementerian Pendidikan dan Kebudayaan.

Dari uraian di atas dapat dipahami bahwa guru pendidikan agama Islam harus berasal dari program studi pendidikan agama dan/atau program studi agama dariPerguruan Tinggi yang terakreditasi dan memiliki sertifikat profesi guru pendidikan agama, dimana pengangkatannya dilakukan oleh pemerintah pusat (melalui Kementerian Agama) atau pemerintah daerah, sehingga tanggung jawab pembinaan guru agama

\footnotetext{
${ }^{21}$ Menteri Agama Republik Indonesia.Peraturan Menteri, hlm. 8.

${ }_{22}$ Menteri Agama Republik Indonesia, Peraturan Menteri, hlm. 8-9.
} 
FITRAH Vol.01 No. 1 Januari - Juni 2015

seharusnya adalah tanggung jawab bersama antara Kementerian Agama, Kementerian Pendidikan dan Kebudayaan serta pemerintah daerah.

\section{PESERTA DIDIK}

Dalam Undang-Undang No. 23 Tahun 2003 Bab V Pasal 12 Ayat (1) tentang Peserta Didik disebutkan bahwa Setiap peserta didik pada setiap satuan pendidikan berhak: (a) mendapatkan pendidikan agama sesuai dengan agama yang dianutnya dan diajarkan oleh pendidik yang seagama. ${ }^{23}$ Sejalan dengan pasal 12 ayat 1 Undang-Undang No. 23 Tahun 2003 di atas, maka dalam Peraturan Pemerintah Republik Indonesia Nomor 55 Tahun 2007 Tentang Pendidikan Agama Dan Pendidikan Keagamaan Bab II pasal 4 ayat 2 dijelaskan bahwa "Setiap peserta didik pada satuan pendidikan di semua jalur, jenjang, dan jenis pendidikan berhak mendapat pendidikan agama sesuai agama yang dianutnya dan diajar oleh pendidik yang seagama".$^{24}$

Sebagai tindak lanjut dari Peraturan Pemerintah Republik Indonesia Nomor 55 Tahun 2007, maka dalam Peraturan Menteri Agama Republik Indonesia No. 16 Tahun 2010, Bab 1 pasal 3 ayat 2, dijelaskan bahwa "Setiap peserta didik pada sekolah berhak memperoleh pendidikan agamasesuai dengan agama yang dianutnya dan diajarkan oleh pendidik yangseagama". ${ }^{25}$ Dalam hal ini hak anak dapat diberikan dalam pelaksanaan pembelajaran di dalam kelas, kegiatan ekstrakurikuler keagamaan, keteladanan dari guru-guru Pendidikan Agama Islam dan guru-guru yang beragama Islam, serta pembiasaan yang dilakukan di lingkungan sekolah. Pembiasaan itu dapat dilaksanakan dengan menciptakan suasana keberagamaan di lingkungan sekolah.

Dari penjelasan di atas tampak bahwa Undang-Undang memberikan kesempatan kepada setiap warganegara untuk memperoleh pendidikan agama sesuai dengan agama yang dianutnya dan diajarkan oleh guru yang seagama.Hal ini dimaksudkan untuk memberikan rasa nyaman kepada peserta didik dan orangtua bahwa pendidikan agama yang diterima peserta didik tidak menyimpang dari ketentuan agama yang dianutnya.Dala hal ini tugas sekolah untuk memberikan hak peserta didik untuk memperoleh pendidikan agama Islam di lingkungan belajarnya.

\section{HARAPAN DAN TANTANGAN}

\section{Harapan}

Penyelenggaraan pendidikan agama di sekolah merupakan kelanjutan dari pendidikan yang dilaksanakan di lingkungan keluarga. “Dengan masuknya anak ke

${ }^{23}$ Undang-Undang No. 20 Tahun 2003, Pasal 12 ayat 1.

${ }^{24}$ Presiden Republik Indonesia, Peraturan Pemerintah, hlm. 2.

${ }^{25}$ Peraturan Menteri Agama No. 16 Tahun 2010, hlm. 5. 
sekolah, maka terbentuklah hubungan antara rumah dan sekolah karena antara kedua lingkungan itu terdapat objek dan tujuan yang sama, yakni mendidik anak-anak". ${ }^{26}$ Dengan demikian harapan dalam penyelenggaraan pendidikan agama Islam di sekolah adalah bermuara pada pencapaian tujuan pendidikan agamaIslam di sekolah umum, yaitu:

Terbentuknya peserta didik yang beriman dan bertakwa kepada Allah Swt., berbudi pekerti yang luhur (berakhlak yang mulia), dan memiliki pengetahuan yang cukup tentang Islam, terutama sumber ajaran dan sendi-sendi Islam lainnya, sehingga dapat dijadikan bekal untuk mempelajari berbagai bidang ilmu atau mata pelajaran tanpa harus terbawa oleh pengaruh-pengaruh negatif yang mungkin ditimbulkan oleh ilmu dan mata pelajaran tersebut. ${ }^{27}$

Tujuan di atas, kemudian dirinci dalam Keputusan Menteri Agama Nomor 211 Tahun 2011 yang isinya adalah Pendidikan Agama Islam bertujuan untuk berkembangnya kemampuanpeserta didik dalam memahami, menghayati, dan mengamalkan nilainilaiagama Islam yang menyerasikan penguasaannya dalam ilmupengetahuan, teknologi dan seni. Pendidikan Agama Islam di sekolah bertujuan untuk:

a. Meningkatkan keimanan dan ketakwaan pada Allah SWT dalam diripeserta didik melalui pengenalan, pemahaman, penghayatan terhadapayat-ayat Allah yang tercipta dan tertulis (ayat kauniyyah dan ayatqauliyyah).

b. Membentuk karakter muslim dalam diri peserta didik melaluipengenalan, pemahaman, dan pembiasaan norma-norma dan aturanaturanIslam dalam melakukan relasi yang harmonis dengan Tuhan,diri sendiri, sesama, dan lingkungannya

c. Mengembangkan nalar dan sikap moral yang selaras dengan keyakinanIslam dalam kehidupan sebagai warga masyarakat, warga negara, danwarga dunia. ${ }^{28}$

Sesuai dengan tujuan di atas, maka pendidikan agama Islam yang dilaksanakan di sekolah dapat dijadikat sebagai sarana untuk meningkatkan pengetahuan, keterampilan, sekaligus pembentukan akhlak mulia, sehingga peserta didik memiliki daya tangkal untuk melakukan filterisasi terhadap berbagai dampak negatif yang ditimbulkan oleh berbagai bidang ilmu yang dipelajarinya atau budaya asing yang tidak sesuai dengan nilai-nilai ajaran Islam.

${ }^{26}$ Zakiah Daradjat, dkk, Ilmu Pendidikan Islam ( Jakarta: Bumi Aksara, 2006), hlm. 76

27Departemen Pendidikan Nasional, Panduan Pengembangan Silabus Mata Pelajaran Pendidikan Agama Islam, (Jakarta: Ditjend Manajemen Pendidikan Dasar dan Menengah Direktorat Pembinaan Sekolah Menengah Pertama, 2006), hlm. 2.

${ }^{28}$ Menteri Agama Republik Indonesia, Keputusan Menteri Agama Republik Indonesia, hlm. 56. 
FITRAH Vol.01 No. 1 Januari-Juni 2015

\section{Tantangan}

Pendidikan agama Islam yang dilaksanakan di sekolah juga tidak terlepas dari berbagai tantangan.Permasalahan-permasalahan yang dapat menjadi tantangan penyelenggaraan pendidikan agama Islam di sekolah umum menurut Saleh ${ }^{29}$ dapat dikategorikan ke dalam berbagai aspek, yaitu:

a. Hasil yang diharapkan. Rumusan tujuan pendidikan agama yang terangkum dalam kata "Meniningkatkan iman dan takwa", merupakan sesuatu yang masih sangat luas. Unsur ketakwaan yang perlu dicapai pada masing-masing jenjang pendidikan mulai dari Sekolah Dasar sampai Perguruan Tinggi perlu dirumuskan, mengingat keterbatasan waktu, fasilitas dan kondisi lingkungan serta spesifikasi jenis dan tingkatan sekolah tertentu.

b. Materi dan alokasi waktu. Luasnya ruang lingkup materi pendidikan agama Islam jika dibandingkan dengan alokasi waktu yang tersedia (2 jam pelajaran/minggu) tidak akan tuntas, jika dihubungkan dengan konsep belajar tuntas.

c. Siswa sebagai peserta didik. Analisis faktual menunjukkan kondisi siswa di sekolah, terutama pada sekolah lanjutan, terdiri dari latar belakang yang sangat bervariasi, mulai dari latar belakang sekolah asal, keluarga dan pengalaman keagamaan. Kondisi seperti ini sangat menyulitkan bagi guru agama dalam melaksanakan tugasnya untuk menyelesaikan program pembelajaran sesuai dengan tuntutan kurikulum.

d. Orangtua siswa. Kondisi orangtua yang cukup sibuk sehingga tidak memiliki waktu luang untuk memantau proses belajar anaknya di rumah (termasuk pendidikan agama) merupakan salah satu permasalahan yang cukup serius dalam penyelenggaraan pendidikan agama Islam.

e. Lingkungan pendidikan. Proses internalisasi nilai-nilai agama yang dilakukan di sekolah seringkali kontradiksi dengan fakta yang terjadi di masyarakat, sehingga peserta didik mengalami kebingungan untuk menentukan pilihan diantara kontradiksi yang terjadi di sekolah dengan masyarakat.

f. Guru agama. Rasio guru agama Islam dengan jumlah siswa, kualitas dan kapasitas keilmuan guru agama, masalah profesionalisme guru agama, dualism birokrasi (Kementerian Agama dan Kementerian Pendidikan Nasional).

Sementara Mu'arif menilai bahwa hadirnya pendidikan agama yang mewarnai wajah pendidikan nasional memiliki banyak kelemahan, baik aspek sistemnya maupun metode pembelajarannya, yang kesemuanya kurang mengakomodir kepentingan-kepentingan

${ }^{29}$ Abdul Rahman Saleh, Pendidikan Agama dan Keagamaan, Visi, Misi dan Aksi (Jakarta: PT. Gemawindu Pancaperkasa, 2000), hlm. 25-28. 
peserta didik dalam rangka pengembangan potensi-potensi mereka. Muarif menilai bahwa guru-guru agama dalam melaksanakan kegiatan pembelajaran hanya memfokuskan diri pada penanaman nilai-nilai moral agama yang ditarnsformasikan secara langsung kepada peserta didik-peserta didik dengan tidak menyematkan metode dialogis dan partisipatoris. Yang terjadi kemudian, peserta didik-peserta didik hanya mewakili dari obyek pembelajaran statisyang menerima transformasi pengetahun dari guru..$^{30}$ Artinya, siswa hanya dibekali teori tanpa disertakan aplikasi dan pembiasaan dalam kehidupan nyata. Sehingga pendidikan agama tidak dapat berpengaruh banyak terhadap prilaku dan moral keseharian peserta didik.

Selain masalah yang disebutkan di atas, masalah metodologi pengajaran agama juga merupakan salah satutantangan pendidikan agama Islam di sekolah umum. Tantangan penyelenggaraan pendidikan agama Islam di sekolah ditinjau dari segi metode adalah sebagai berikut:

a. Kurang bisa mengubah pengetahuan agama yang kognitif menjadi makna dan nilai atau kurang mendorong penjiwaan terhadap nilai-nilai keagamaan yang perlu diinternalisasikan dalam diri peserta didik.

b. Kurang dapat berjalan bersama dengan program-program non agama.

c. Kurang mempunyai relevansi terhadap perubahan sosial yang terjadi di masyarakat atau kurang ilustrasi sosial budaya, atau bersifat statis akontekstual dan lepas dari sejarah, sehingga pendidik kurang menghayati nilai-nilai agama sebagai nilai yang hidup dalam keseharian. ${ }^{31}$

Dari uraian di atas dapat dipahami bahwa tantangan pendidikan agama di sekolah umum adalah rumusan tujuan pendidikan agama yang terlalu luas, luasnya ruang lingkup materi pendidikan agama Islam jika dibandingkan dengan alokasi waktu yang tersedia, kondisi siswa di sekolah, yang sangat bervariasi, mulai dari latar belakang sekolah asal, keluarga dan pengalaman keagamaan sehingga guru agama dalam melaksanakan tugasnya, kondisi orangtua yang cukup sibuk sehingga tidak memiliki waktu luang untuk memantau proses belajar anak, proses internalisasi nilainilai agama yang seringkali kontradiksi dengan fakta yang terjadi di masyarakat, rasio guru agama Islam dengan jumlah siswa, kualitas dan kapasitas keilmuan guru agama, masalah profesionalisme guru agama, dualisme birokrasi (Kementerian Agama dan Kementerian Pendidikan Nasional) dan metodologi yang kurang relevan.

${ }^{30}$ Muarif, Liberalisasi Pendidikan: Menggadaikan Kecerdasan Kehidupan Bangsa (Yogyakarta: Pinus Book Publisher, 2008), h. 56.

${ }^{31}$ Muhaimin, Pengembangan Kurikulum Pendidikan Agama Islam (Jakarta: Raja Grafindo Persada, 2005), hlm. 27. 
FITRAH Vol.01 No. 1 Januari - Juni 2015

\section{PENUTUP}

Dari pembahasan yang dilaksanakan dapat diambil kesimpulan bahwa penyelenggaraan pendidikan agama di sekolah umum dalam kurun waktu 2003 s.d 2014 telah mengalami perkembangan, dan upaya penyempurnaan baik dari segi perundanganundangan, kurikulum, jam pelajaran, keguruan dan anak didik yang dimulai dari UUSPN No. 20 Tahun 2003, Peraturan Pemerintah Nomor 55 tahun 2007, Peraturan Menteri Agama Nomor 16 Tahun 2010, Keputusan Menteri Agama Republik Indonesia Nomor 211 Tahun 2011, Penerapan Kurikulum 2013, Penerapan Permendikbud Nomor 160 Tahun 2014 dan Surat edaran Menteri Agama Nomor SE/D.3.1/PP.00/143/2015 tentang Implementasi Kurikulum 2013.

Pendidikan agama yang diberikan di sekolah memberikan harapan terhadap pengembangan keimanan dan ketakwaan peserta didik, penanaman nilai-nilai ajaran Islam, menyesuaikan mental peserta didik terhadap lingkungan sosial, memperbaiki kesalahan dan kelemahan peserta didik dalam hal keyakinan dan pengamalan agama, menjadi filter terhadap dampak negatif budaya asing, memberikan pengetahuan agama secara umum, dan memberikan modal kepada peserta didik untuk mendalami pendidikan agama kepada lembaga pendidikan yang lebih tinggi.

Berbagai permasalahan dan tantangan yang dihadapi dalam penyelenggaraan pendidikan agama Islam membutuhkan inrospeksi dari semua pihak terkait dalam upaya melakukan perbaikan, sehingga tujuan penyelenggaraan pendidikan agama Islam di sekolah dapat dicapai secara maksimal. Untuk itu diperlukan sinergivitas dari seluruh komponen terkait, terutama Kementerian Agama, Kementerian Pendidikan dan Kebudayaan dan Pemerintah Daerah untuk menyamakan persepsi terhadap pelaksanaan pendidikan agama Islam di sekolah. Hal ini dimaksudkan agar guru agama Islam memiliki acuan yang jelas dalam penyelenggaraan pendidikan agama Islam di sekolah. Solusi yang tidak kalah pentingnya adalah membumikan nilai-nilai ajaran Islam di lingkungan sekolah dengan menciptakan suasana keberagamaan di lingkungan sekolah. Dengan demikian pendidikan agama Islam di sekolah tidak sebatas berorientasi pada belajar tentang agama dengan mengedepankan aspek kognisi daripada apeksi dan psikomotorik, tetapi lebih kepada pengamalan nilai-nilai ajaran agama di lingkungan sekolah yang diwujudkan dalam sikap dan prilaku dalam kehidupan sehari-hari.Selain itu peran Kelompok Kerja Guru dan Musyawarah guru Mata Pelajaran perlu dioptimalkan sebagai wadah bertukar informasi, berlatih, bertukar pengalaman bagi guru sehingga dapat saling berbagi pengalaman dalam meningkatkan kualitas pembelajaran pendidikan agama Islam di sekolahnya. 


\section{DAFTAR PUSTAKA}

Abdul Rahman Saleh. Pendidikan Agama dan Keagamaan, Visi, Misi dan Aksi. Jakarta: PT. Gemawindu Pancaperkasa, 2000.

Departemen Pendidikan Nasional, Panduan Pengembangan Silabus Mata Pelajaran Pendidikan Agama Islam.Jakarta: Ditjend Manajemen Pendidikan Dasar dan Menengah Direktorat Pembinaan Sekolah Menengah Pertama, 2006.

Menteri Agama Republik Indonesia.Peraturan Menteri Agama Republik Indonesia Nomor 16 Tahun 2010 Tentang Pengelolaan Pendidikan Agama Pada Sekolah.Jakarta: Sekretariat Negara, 2010.

Menteri Agama Republik Indonesia.Keputusan Menteri Agama Republik Indonesia Nomor 211 Tahun 2011 Tentang Pengemnbangan Standar PAI Pada Sekolah.Jakarta: Kementerian Agama RI, 2011.

Kunandar. Guru Profesional Implementasi Kurikulum Tingkat Satuan Pendidikan (KTSP) dan Sukses dalam Sertifikasi Guru.Jakarta: Raja Grafindo Persada, 2010.

Lampiran 1 Peraturan Menteri Pendidikan Dan Kebudayaan Nomor 58 Tahun 2014 Tentang Kurikulum 2013 Sekolah Menengah Pertama/Madrasah Tsanawiyah.

Lampiran peraturan menteri pendidikan nasional Nomor 22 tahun 2006 Tanggal 23 mei 2006, Standar Isi. Jakarta: BSNP, 2006.

Menteri Pendidikan dan Kebudayaan Republik Indonesia, Peraturan Menteri Pendidikan dan Kebudayaan Nomor 160 Tahun 2014 Tentang Pemberlakuan Kurikulum 2006 dan 2013.

Muarif. Liberalisasi Pendidikan: Menggadaikan Kecerdasan Kehidupan Bangsa. Yogyakarta: Pinus Book Publisher, 2008.

Muhaimin. Pengembangan Kurikulum Pendidikan Agama Islam.Jakarta: Raja Grafindo Persada, 2005.

Omar Hamalik. Pengembangan Kurikulum.Bandung: Remaja Rosda Karya, 2006.

Presiden Republik Indonesia.Peraturan Pemerintah Republik Indonesia Nomor 55 Tahun 2007 Tentang Pendidikan Agama Dan Pendidikan Keagamaan. Jakarta: Sekretariat Negara, 2007.

Surat Edaran Nomor SE/D.3.1/PP.00/143/2015 Tentang Implementasi Kurikulum 2013 Pendidikan Agama Islam (PAI) Pada Sekolah. 
FITRAH Vol.01 No. 1 Januari - Juni 2015

Undang-Undang No. 14 Tahun 2005 Tentang Guru dan Dosen.

Undang-Undang No. 20 Tahun 2003 Tentang Sistem Pendidikan Nasional, Bab II Pasal 3.

Zakiah Daradjat. Dkk.Ilmu Pendidikan Islam. Jakarta: Bumi Aksara, 2006. 